\title{
Effects of UTAUT 2 Model on the Use of BCA Mobile Banking in Indonesia
}

\author{
Aniek Susilowatia ${ }^{a}$ Bambang Rianto ${ }^{b}$, Natasya Wijaya $^{c}, \operatorname{Lim}_{\text {Sanny }}{ }^{\mathrm{C}^{*}}$ \\ a , b, c, d Business Management Program, Management Department, BINUS Business School Master Program, Bina Nusantara \\ University, Jakarta, Indonesia 11480 \\ d*1sanny@binus.edu
}

Article History: Received: 10 November 2020; Revised 12 January 2021 Accepted: 27 January 2021; Published online: 5 April 2021

\begin{abstract}
Purpose - The m-banking service is a long-distance transaction platform that is innovative and strategic product provided by financial institution. It has succeeded in removing physical limitation of banking activities through the use of mobile device by customers. Support for the advance in internet technology bringing about considerable and continuous changes in banking operational have enabled customers to connect with business world and make transaction at any time, so that it also changes how customers use banking services. The World's Best Bank has positioned BCA as a bank capable of adapting to pandemic situation because its banking services related to technology is considered as the best. Therefore, this research recognizes the need for testing factors affecting BCA customers to adopt and continue to use BCA m-banking service. Design/methodology/approach - the conceptual relationship of behavior intention on the acceptance and the use of information technology in this research used UTAUT2 model. Primary data were processed using SEM method with SMART-PLS software collected from survey questionnaires carried out to 400 respondents having BCA accounts and using BCA m-banking in the last 3 months.

Findings - the main factors such as habit, hedonic motivation and facilitating condition were found to provide significant effect on behavior intention of customers to adopt and use BCA m-banking service.

Practical implications - the findings are expected to educate public about m-banking service capable of facilitating banking transaction and recommending banking system to provide a safe m-banking service and it also requires sustainable development.
\end{abstract}

Keywords: Indonesia, Adoption, Mobile banking, UTAUT

\section{Introduction}

The advance in internet technology brings about considerable changes in banking operational, for example, the use of m-banking service as the innovative service providing additional values (Tiwari \& Buse, 2007) to improve life quality and efficiency offered by bank (Malaquias and Hwang, 2016). It also allows the customers to make banking transaction via smartphone (Riswandi, 2005). The recent advance in the field of cellular technology also makes a considerable and continuous change in using m-banking in the financial sector (Alalwan, Dwivedi, \& Rana, 2017; Gupta, 2019; Lin, 2011; Rana, Dwivedi, Lal, Williams, \& Clement, 2017; Shaikh \& Karjaluoto, 2015; Zhang, Weng, \& Zhu, 2018; Zhou, 2012)

M-banking has uniqueness because it has different system quality, information, and services, but it is more advanced compared to the previous e-banking service such as computer, kiosk and laptop (Tam \& Oliveira, 2017). M-banking is a platform facilitating banking transaction via mobile phone connected to internet (Lin, 2011). Therefore, m-banking allows its customers to be connected to business world at any time and make transaction at the same time and in turn; it has changed the used of banking services (Aboelmaged \& Gebba, 2013). Identification of factors affecting the level of the use of technology has been considered as the important objective to change characteristic of technology service, so that its adoption can be more interesting (Baabdullah, Alalwan, \& Al Qadi, 2018; Kuisma, Laukkanen, \& Hiltunen, 2007). Based on the reasons, people tend to adopt and switch to use m-banking service.

M-banking is m-commerce application provided by the financial institution or bank and by using mobile device such as cellular phone or smartphone, customers can enter into long-distance financial transaction (Al-Jabri \& Sohail, 2012). Traditional bank service is limited to physical canal such as bank branch and Automatic Teller Machine (ATM), whereas m-banking has removed the physical limitation from daily banking activities. In addition to innovative and strategic character, m-banking services also allow lower operation costs (Baptista \& Oliveira, 2015), and higher quality in services offered (Moser, 2015). The organization ability to make innovation is considered as significant to develop and maintain competitive advantage in this technology era (Tiddet et al, 2001). According to Forbes and Statista, BCA Bank operating in Indonesia is in the first position of The World's 
Best Banks because BCA bank is able to adapt to pandemic situation, then it is considered to have fulfilled five assessment sub-dimensions, such as trust, terms and conditions, customer service, digital service, and financial advice, where its banking solution and services related to technology is considered as the best. The aim of this research is to find factors affecting BCA customers to adopt and keep using BCA m-banking services.

The research about the acceptance of m-banking in several developing countries showing factor affecting the acceptance of $\mathrm{m}$-banking reveals inconsistent results. The research about $\mathrm{m}$-banking adoption in Ghana performed by Kwateng et al, (2018) showed that the main motivation to adopt and to use m-banking service were habit, price value, and trust factors. Model construction, performance expectancy, effort expectancy, social influence and hedonic motivation factors did not provide significant effects on consumers' behavior intention to adopt and use technology (Kwateng et al, 2018). Another research in Saudi Arabia performed by Baabdullah et al, 2018 showed the result of m-banking adoption was significantly affected by performance expectancy, facilitating conditions, price value, hedonic motivation, habit, system quality, and service quality. In the other hand, there was a research showing different results, especially in social influence, effort expectancy variables that provided significant effects on technology adoption. Research performed in Pakistan showed that m-banking adoption was significantly affected by price value felt, performance expectancy, habit, social influence, effort expectancy, hedonic motivation, including risk and trust felt. All predictor behavior use provided significant effects, yet consumer adoption intentions did not provide significant effects on facilitating conditions (Farah et al, 2018). Different results of these research took our attention, given that social influence that was the preference and social values, including family members, friends, relatives, neighbors, and other technology users usually tend to drastically change users' perception and point of view (Alsheikh \& Bojei, 2014; Rana, Dwivedi, \& Williams, 2015). Especially in social media era today, where words of mouth dominated cyber world (Dwivedi et al., 2018; Kapoor et al., 2018; Roy, Singh, Baabdullah, Kizgin, \& Rana, 2018). The positive role of social influence in the use of m-banking was also emphasized by Al-Husein \& Sadi (2015) in the Saudi Arabia context. Meanwhile, effort expectancy was how users feel to be connected to convenient and easy to use technology (Alalwan et al., 2017; Ozturk, Bilgihan, Nusair, \& Okumus, 2016; Shareef, Dwivedi, Kumar, \& Kumar, 2017). Easy technology accessibility tended to motivate users in adopting technology (Dwivedi, Rana, Janssen et al., 2017; Oliveira et al., 2014). However, only Farah et al, 2018 research found that both variables (social influence and effort expectancy) provided significant effects on technology adoption, in this case, m-banking, while two other research revealed that both variable did not provided significant effects.

Based on the discussion above, it shows that several previous research had enough evidence to prove that this topic still needs to be addressed. There are still many inconsistent/contradictive findings/unresolved argumentation related to the questioned topic. We find different effects among several variables such as effort expectancy and social influence on behavior intention of m-banking users, therefore, it is important to perform further research on the effect of the variables in Indonesia, especially factors affecting the use of BCA m-banking.

Many factors affect the adoption of the use of m-banking, but they are by using UTAUT2 model. The objective of this research is to find which key factor in Indonesian people significantly affects the adoption of $\mathrm{m}-$ banking use, especially BCA consumers. As a result, this research will provide contribution to find what factors from variables in UTAUT2 model, Performance Expectancy, Effort Expectancy, Social Influence, Facilitating Condition, Hedonic Motivation, Price Value and Habit affecting the use of $\mathrm{m}$-banking in Indonesia, especially BCA bank.

\section{Literature Review}

There are quite a lot of studies related to m-banking (for example, Al-Jabri \& Sohail, 2012; Baptista \& Oliveira, 2015; Choudrie, Junior, McKenna, \& Richter, 2018; Lee \& Chung, 2009; Yu, 2012; Zhou, 2011) in various contexts (for example, Saudi Arabia, South Korea, Taiwan, and Mozambique) testing variables that might affect the use of m-banking. Several research performed during 2017 to 2018 examined the main factor and aspects predicted to affect intentions, behavior, and attitude to m-banking (Asongu \& Nwachukwu, 2018; Malaquias, Malaquias, \& Hwang, 2018; Mehrad \&Mohammadi, 2017; Sampaio, Ladeira, \& Santini, 2017; Singh \& Srivastava, 2018; Shareef, Baabdullah, Dutta, Kumar, \& Dwivedi, 2018; Tam \& Oliveira, 2017; Warsame \& Ireri, 2018). This explains that m-banking still becomes subject that is worth to be scrutinized and learnt. Malaquais et al, (2018) convinced the importance of tracking fluctuations of the level of the use of $\mathrm{m}$ banking from time to time. Based on the results found in the longitudinal research performed by Malaquais et, al (2018), it was also added that by spending time using m-banking, the Brazilian banking customers tended to have positive perspective regarding particular aspects, such as trust, performance, expectancy, performance expectancy and perceived ease of use. Mehrad and Mohammadi (2007) had performed a research on the effects of recommendation and advice from people around the customers able to predict their intention to use m-banking. It turns out that words of mouth have been proven to provide significant effects on the customers attitude that eventually will affect actual use behavior. 
Many methods are used to test the acceptance of technology, one of which is UTAUT2. UTAUT was used because it is a further development of UTAUT considered as acceptance model and technology use combining the best features from other eight existing acceptance model theories. UTAUT was first introduced by Venkatesh et al, (2003). This model was introduced after comparing several previously existing theories and models, such as Technology Acceptance Model (TAM); Motivational Model (MM); the Theory of Reasoned Action (TRA); the Theory of Planned Behavior (TPB); Combined TAM and TPB (CTAM-TPB); Social Cognitive Theory (SCT); Innovation Diffusion Theory (IDT); the Model of PC Utilization (MPCU); the Unified Theory of Acceptance and Use of Technology (UTAUT). At the beginning, the UTAUT model had 4 independent variables that were always used, such as gender, age, experience, and voluntaries. In contrast, Venkatesh et al, (2012) introduced UTAUT2 with 3 additional variables on UTAUT model, which were price value, hedonic motivation and habit to improve the strength of model measurement. In addition, there were also only 3 moderating variables used, which were age, experience and gender to develop UTAUT2, so it can be applied in the context of consumers' use. UTAUT2 has been widely used and adopted in around the world to predict technology acceptance and use (Abushanab \& Pearson, 2007; Oliveira et al., 2014; Baptista \& Oliveira, 2015; Tarhini et al., 2016; Gupta et al., 2019),

Performance expectancy was defined as in what extent the use of technology would provide benefits for consumers and perform particular activities (Venkatesh et al, 2003). Performance expectancy actually measured to what extent someone believed that using m-banking service would help them in making banking transaction (Tarhini et al., 2016). Oliveira et al., (2014) and Sarfaraz (2017) concluded that performance expectancy totally affected behavior intention to use m-banking. Baptista \& Oliveira (2015) and Basri (2018) empirically showed that the use of m-banking believed that performance expectancy was one of the most important antecedents from behavior intention. In the other hand, research performed by Owusu Kwateng et al, (2018) showed that performance expectancy did not provide effects on behavior intention. Based on the arguments above, this research formulated hypothesis stating that:

\section{H1: performance expectancy provides positive and significant effects on behavior intention.}

Venkatesh et al, (2003) stated that effort expectancy was an ease level related to system use. The easier the use of m-banking was, the higher the possibility of users to use it to make their banking transaction. In their research Bankole et al, (2011) exploring m-banking antecedents in Nigeria, had proved that effort expectancy provided positive effect on behavior intention to use m-banking service. Bhatiasevi (2016) drew the same conclusion in the research performed to identify factors affecting m-banking adoption in Thailand. It was the same with Albashrawi et al, (2017), by observing sample of bank consumers in US. However, the research performed by Baabdullah et al, (2019) showed different results, where effort expectancy did not provide effects on m-banking in Saudi Arabia and it was also supported by research performed by Owusu Kwateng wt al, (2018) showing that effort expectancy did not provide effects on behavior intention. Based on the above arguments, this research formulated hypothesis stating that:

H2: effort expectancy provides significant and positive effects on behavior intention.

Social influence was opinion and expectation appearing from users' social environment, including families, friends, or colleagues and it significantly formed their behavior intention to use a technology (Venkatesh et al, 2012). This correlation has proven to be statistically significant in the context of m-banking (Talukder et al., 2014; Goncalves et al., 2018), and it also has proven to be increased as users' age. Older people were more susceptible to the opinions of others than their younger counterparts (Venkatesh et al., 2003). It was also associated with the increasing need for affiliation in general related to age (Morris and Venkatesh, 2000). The positive role of social influence in using m-banking was highlighted by Al-Husein and Sadi (2015) in the context of Saudi Arabia. In contrast, the research results in Saudi Arabia performed by Baabdullah et al, (2019) showed that social influence did not provide substantial effects on the use of m-banking. Based on the above arguments, this research formulated hypothesis stating that:

H3: social influence provides positive and significant effects on behavior intention.

Facilitating conditions are defined as a security to consumers because facilities and supporting system to use technology innovation were available (Venkatesh et al., 2003 in Owusu Kwateng et al., 2018). The use of mobile and internet banking still existed, and it was strongly related various resources and infrastructures, such as smartphone and internet connection (Tarhini et al., 2016 in Merhi et al., 2020). In general, the existing users had tendency to face more challenges in processing new and complex information, so it affected their learning about new technology (Morris et al., 2005; Plude \& Hoyer, 1985 in Owusu Kwateng et al., 2018). The research performed by Baabdullah et al, (2019) found that facilitation conditions provided positive and significant correlation with the use of m-banking in Saudi Arabia. However, in some research performed by Owusu Kwateng 
er al, (2018) Farah et al., 2018 and El-Masri et al., 2017, it was found that facilitating conditions did not provide significant effects on behavior intention. Based on the above arguments, this research formulated hypothesis stating that:

H4: facilitation condition provides positive and significant effects on behavior intention.

In the consumers' context, hedonic motivation became defining factor for the acceptance and the use of technology (Brown \& Venkatesh, 2005; Childers et al., 2001). Hedonic motivation was "a pleasure and enjoyment obtained by the use of technology" (Venkatesh et al., 2012). When the consumers found that technology, they used provided them pleasure, enjoyment, comfort and satisfaction, they would tend to not change technology they used into other competitor technology (Alalwan, Rana, Dwivedi, Lal, \& Williams, 2015; Baabdullah, 2018; Koenig-Lewis et al., 2010). An individual was motivated to adopt m-banking service that met their aesthetic and emotional needs ( $\mathrm{Li}$ et al, 2012). The research have shown that the use of interactive service, such as m-banking application, was not only based on functional motivation, but it was greatly motivated by hedonic needs and values (Malaquias \& Hwang, 2016). The effect of hedonic motivation on the use of m-banking has been mentioned in several studies (e.g Alalwan et al., 2017; Dwivedi, Rana, Janssen et al., 2017; Dwivedi, Rana, Jeyaraj et al., 2017; Zhou et al., 2010; Yu, 2012). However, in the research performed by Merhi et al, (2019) in Lebanon and England, it was found that hedonic motivation did not provide significant effects on behavior intention. Based on the above arguments, this research formulated hypothesis stating that:

H5: hedonic motivation provides positive and significant effects on behavior intention.

Price value was defined as price value that was in accordance with benefits felt by the users from a technology compared to costs related to its use (Brown \& Venkatesh, 2005 in Merhi et al, 2000), how prices and costs affect the consumers to use a technology. For example, in the marketing research, to test the value attached to product/service, price/cost analysis was generally considered in relation to the quality of product/service (Zeithaml, 1988 in Owusu Kwateng et al., 2018). Users tended to use the desired technology with sufficient benefits to offset the monetary costs required (Oliveira et al., 2014 in Merhi et al., 2020). In the context of mbanking, the price value can be explained by the trade-off between the costs incurred for downloading, installing and using the application without taking into account the perceived value of its use (Thusi \& Honey, 2020). Moreover, perceptions of price value were suggested to be adjusted with social roles (which vary according to age), a theory which was then validated in the context of the IS study (Venkatesh et al., 2012 in Merhi et al., 2020). Research performed by Owusu Kwateng et al., 2018; Merhi et al., 2020 and Alalwan et al., 2018 stated that price value provided significant effect on behavior intention. However, research performed by El-Masri \& Tarhini (2017) and Thusi \& Maduku (2020) found the opposite, where price value did not provide significant effect on behavior intention. Based on the above arguments, this research formulated hypothesis stating that:

H6: price value provides positive and significant effects on behavior intention.

Habit was defined as the extent to which a person performed certain behaviors automatically and repeatedly based on experience and knowledge gained from time to time (Alalwan et al., 2015). A consumer found it difficult to change habits and therefore, was likely to reject new and unfamiliar interactions with his bank (Chemingui \& Hajer, 2013). This in turn raised consumers' doubts about adopting new applications and services such as mbanking (Antón et al., 2013). In fact, past experiences and habits tended to be subconscious elements that can significantly hindered consumers' desire to learn new methods because they tended to rely on past experiences when making decisions rather than using cognitive reasoning (Venkatesh et al., 2016; Zhang et al., 2017). Likewise, consumers who took advantage of offline banking were familiar with the habits and abilities needed to make offline transactions while, they needed to develop new habits and skills to take advantage of the m-banking application (Hanafizadeh et al., 2013). Therefore, previous research has identified habits as one of the main barriers to individual adoption of new technologies as they provided significant effects on consumer preferences and intentions (Moorthy et al., 2017). Repeated use of m-banking gradually increased the activity in using this service compared to e-banking (Huili \& Zhong 2011). However, in a research performed by Mahfuz et al., 2016, there were different results where habit did not provide significant effects on behavior intention. Based on the above arguments, this research formulated hypothesis stating that:

H7: habit provides positive and significant effects on behavior intention.

\section{Methodology}

The population of this study was account owners and users of $m$-banking services in Indonesia from various socio-cultural and economic backgrounds with the growth of smartphones and internet use who had businesses or jobs in both the formal and informal sectors. This research used a non-probability sampling method of m-banking users at BCA in Indonesia. With a purposive sampling approach, the researcher selected respondents having the ability and experience in various perspectives on m-banking (Denzin \& Lincoln, 2005), with the criteria that 
respondents had a BCA savings account connected to m-Banking facilities and had used BCA m-banking at least 3 last month. Researchers wanted to obtain more accurate and reliable information about the material under study and seek the most appropriate sampling method for this study, so the purposive sampling approach was considered to be the most appropriate. Researchers used primary data collected from a survey with questionnaires of 400 respondents having accounts at BCA and using BCA m-banking. The number of samples were 400, determined using the Lemeshow formula, given that the total population was not exactly known. Following is the calculations:

$$
\begin{aligned}
& n=\frac{z 1-\alpha / 2 P(1-P)}{d^{2}} \\
& n=\frac{1.96^{2} .0 .5(1-0.5)}{0.0025} \\
& n=\frac{3.8416 .0 .25}{0.0025} \\
& n=384.16=400 \\
& \mathrm{n}=\text { number of sample } \\
& \mathrm{z}=\text { z score at confidence of } 95 \%=1.96 \\
& \mathrm{P}=\text { maximum estimation }=0.5 \\
& \mathrm{D}=\text { alpha }(0.05) \text { or error sampling }=5 \%
\end{aligned}
$$

Data processing method used in this research was SEM method using SMART-PLS 3.0 software for windows to test the measurement model (outer model),to determine the validity and reliability of the model and the structural model (inner model), to determine the relationship between variables and hypothesis testing.

\section{Results and Discussion}

From a total of 413 respondent data, the demographic distribution was dominated by male respondents, which were 229 respondents $(55.4 \%)$, while female respondents were $184(44.6 \%)$. The age of respondents was dominated by the millennial generation 25-32 years old, which was $122(29.5 \%)$, followed by 17-24 years old, which was $106(25.7 \%), 41-48$ years old, which was 77 (18.6\%), 49-56 years old, which was $71(17.2) \%), 33-40$ years, which was $34(8.2 \%)$ and at least was 3 people whose ages were over 57 years old $(0.7 \%)$. This showed that banking transactions through m-banking were more attractive to young people. The most recent education level of respondents was bachelor's degree level with 257 (62.2\%), followed by Senior High School with 97 (23.5\%), D3 with $24(8.8 \%)$, and master's degree with 35 (8.5\%). These results also showed that transactions made using mbanking was found to be higher on people with higher levels of education.

By using the SMART PLS 3.3 software, the measurement model testing was carried out by analyzing several indicators including convergent validity, discriminant validity, and reliability tests. Convergent validity was assessed based on the outer loadings of each indicator or questionnaire item for each variable, namely Performance Expectancy (PE), Effort Expectancy (EE), Social Influence (SI), Facilitating Conditions (FC), Hedonic Motivations (HM), Price Value (PV), Habit (HT) and Behavior Intentions (BI). The results of the analysis showed that there were two items that did not meet the validity criteria set for the FC latent variable (FC3 and FC6 indicators). Therefore, the next analysis did not include these two indicators. As for other variables, all indicators showed that the factor loading met the specified criteria (factor loading $>0.7$ ). After performing reanalysis by excluding the FC3 and FC6 indicators, the results of the analysis showed that each indicator in each variable met the criteria.

After being stated as valid and reliable, the next analysis was structural model analysis. The analysis carried out included the interpretation of the R2 value, the path coefficient, and the t-value of the regression analysis carried out. The results of the analysis showed that the regression model tested can predict the dependent variable very well or moderately, it tended to be strong, with $\mathrm{R} 2=0.679$. This meant that $67.9 \%$ of the variance of the BI score can be predicted from all the independent variables tested, the remaining $32.1 \%$ was affected by other factors.

The significance of the role of each independent variable in the regression model can be seen from the value of the path coefficient $(\beta)$. The analysis results showed that of the 7 latent variables tested, only 3 of which had a significant unique contribution, where the highest effect was Habit, which was shown from the highest path coefficient $(\beta=0.616, \mathrm{t}=8.384, \mathrm{p}<0.01)$. This meant that $\mathrm{H} 7$ was accepted, which was, habit $(\mathrm{HT})$ was proven to 
provide positive and significant effects on behavior intention. The behavior of respondents in using m-banking occurred automatically and repeatedly based on experience and knowledge gained from time to time (Alalwan et al., 2015). This was in line with previous research that has identified habits as one affecting consumer preferences and intentions (Moorthy et al., 2017). This also supported research (Huili \& Zhong 2011) which concluded that repeated use of m-banking gradually increased activity in using m-banking services. The next supported hypothesis was $\mathrm{H} 5$, meaning that hedonic motivation was proven to provide significant effect on behavior intention. This was indicated by the results of Hedonic Motivation (HM) with a value $(\beta=-0.148, t=3.242, p$ $<0.05)$. The results of this research indicated that the motivation of customers to use m-banking was not because they obtained pleasure, enjoyment, comfort, and satisfaction from using m-banking (Alalwan, Rana, Dwivedi, Lal, \& Williams, 2015; Baabdullah, 2018; Koenig-Lewis et al., 2010) but because it has become a habit. These results supports a number of previous studies (eg Alalwan et al., 2017; Dwivedi, Rana, Janssen et al., 2017; Dwivedi, Rana, Jeyaraj et al., 2017; Zhou et al., 2010; Yu, 2012). The third hypothesis which was supported was H4, where the facilitation condition was proven to provide positive and significant effects on behavior intention with the result $(\beta=0.132, \mathrm{t}=2.070, \mathrm{p}<0.05)$. This mean that customer interest in using $\mathrm{m}$-banking depended on the availability of facilities, internet connection, resources and infrastructure such as smartphones. These results support the research performed by Rahi et al., (2019) and Baabdullah, et al., (2019) which concluded that facilitation conditions provided positive and significant relationship to the use of m-banking in Saudi Arabia. Meanwhile, 4 other latent variables showed insignificant contributions, namely $\operatorname{PE}(\beta=0.28, \mathrm{t}=0.596), \mathrm{EE}(\beta=$ $0.094, \mathrm{t}=1.853)$, SI $(\beta=0.070, \mathrm{t}=0.330) \mathrm{PV}(\beta=0.79, \mathrm{t}=1.457)$, and all $\mathrm{p}>0.05)$.

From the overall results of data analysis, it can be concluded that hypothesis 4 , hypothesis 5 , and hypothesis 7 were accepted and supported by the data. Meanwhile, other hypotheses were rejected because they were not supported by data.

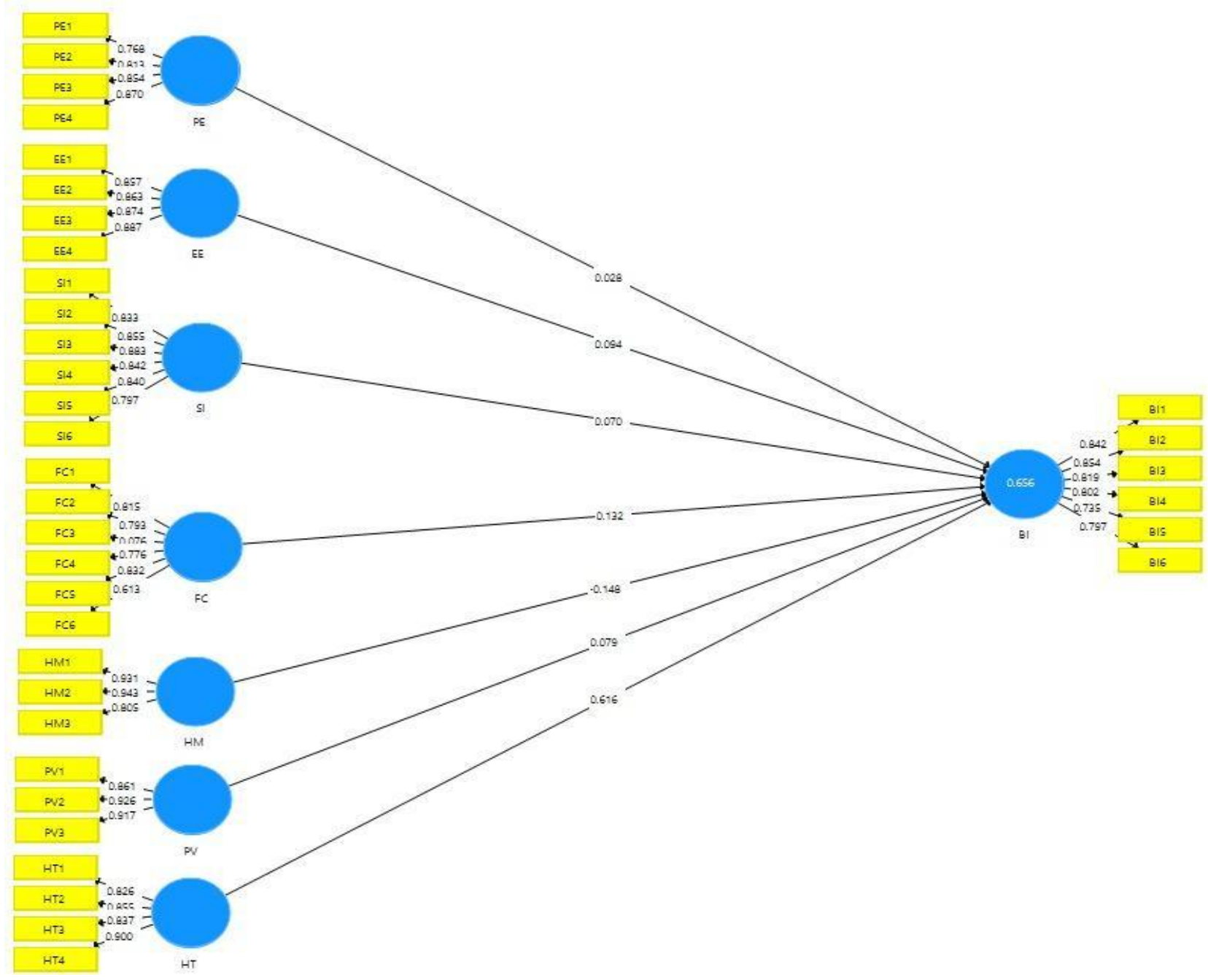

Figure 1. Results Model 


\section{Conclusions}

The results of this research can answer the researcher's question that the factors affecting customers to adopt and use BCA m-banking services were Habit, Hedonic Motivation and Facilitating Condition. Portraits of respondents who were dominated by young people ranging in age from 17 to 23 years old in this study tended to use m-banking automatically and repeatedly so that it formed a habit which was shown from the results of hypothesis testing where habit provided positive and significant effects on the use of m-banking. However, it was also found that BCA customers in this research used m-banking was not because they were motivated to obtain pleasure and comfort, it can be seen from the results of hypothesis testing where Hedonic Motivation provided negative and significant effects. This was supported by the results of the Facilitating Condition hypothesis test providing positive and significant effects on the use of m-banking, where the interest of BCA customers in using m-banking was also affected by the availability of facilities, resources, and infrastructure such as smartphones, internet connection and accompanying technological innovations.

The implication of this research is expected to provide insight and contribution for the development of knowledge in the field of information systems, especially in the behavior of using m-banking. Given the limitations of this study, it is expected that further research related to the interest and behavior of using m-banking can be developed with more complex factors so that this research can be used on a broader scale. For business actors in the banking sector, especially BCA, this study is expected to provide information on the interests and behavior of m-banking users that can be used as a consideration for decision making in banking strategies, particularly to improve the quality of m-banking services for customers. This research is also expected to educate the public about m-banking services that can provide convenience in making banking transactions. We recommend banking business actors, especially $\mathrm{BCA}$, to provide safe m-banking services for customers related to the security risks of the m-banking application and the need to continuously develop m-banking features and benefits such as one smartphone that can be connected to several accounts, using additional security with face id or touch id, developing deposit and investment account opening through m-banking and extending account mutation history inquiry to 1 year according to the suggestions of several respondents in this study.

\section{References}

Abdullah Mahfuz, M., Hu, Wang, Khanam, Liza. (2016). The Influence of Cultural Dimensions and Website Quality on m-banking Services Adoption in Bangladesh: Applying the UTAUT2 Model Using PLS. Association for Information Systems.

Abu Shanab, E. and Pearson, J.M. (2007), Internet banking in Jordan: the unified theory of acceptance and use of technology (UTAUT) perspective, Journal of Systems and Information Technology, Vol. 9 No. 1, pp. 78-97.

Alalwan, A. A., Dwivedi, Y. K., \& Rana, N. P. (2017). Factors influencing adoption of mobile banking by Jordanian bank customers: Extending UTAUT2 with trust. International Journal of Information Management, 37(3), 99-110.

Alalwan A, Dwivedi YK, Rana NP et al (2018). Examining factors influencing Jordanian customers' intentions and adoption of internet banking: Extending UTAUT2 with risk. Journal of Retailing and Consumer Services. 40:125-138.

Al-Jabri, I. M., \& Sohail, M. S. (2012). Mobile banking adoption: Application of diffusion of innovation theory. Journal of Electronic Commerce Research, 13(4), 1-13.

Alsheikh, L., \& Bojei, J. (2014). Determinants affecting customer's intention to adopt mobile banking in Saudi Arabia. International Arab Journal of e-Technology, 3(4), 210-219.

A. Shaikh, H. Karjaluoto. (2015), "Mobile banking adoption: a literature review", Telematics and Informatics, Vol. 32, No. 1, pp. 129-142.

Al-Husein, M., \& Sadi, M. A. (2015). Preference on the perception of mobile banking: A Saudi Arabian perspective. European Online Journal of Natural and Social Sciences, 4(1), 161.

Armitage, C., \& Christian, C. (2003). From attitude to behaviour: Basic and applied research on the theory of planned behaviour. Current Psychology: Developmental, Learning, Personality, Social, 22, 187-195.

Asongu, S., \& Nwachukwu, J. C. (2018). Comparative human development thresholds for absolute and relative pro-poor mobile banking in developing countries. Information Technology and People, 31(1), 63-83.

Baabdullah, A. M., Alalwan, A. A., \& Al Qadi, N. S. (2018). Evaluating the current situation of Mobile services (M-services) in the Kingdom of Saudi Arabia. Emerging markets from a multidisciplinary perspective. Cham: Springer 149-160.

Baabdullah, A. M., Alalwan, A. A., Rana, N. P., Kizgin, H., \& Patil, P. (2019). Consumer use of mobile banking (M-Banking) in Saudi Arabia: Towards an integrated model. International Journal of Information Management, 44, 38-52. doi:10.1016/j.ijinfomgt.2018.09.002

Baptista, G., \& Oliveira, T. (2015). Understanding mobile banking: The unified theory of acceptance and use of technology combined with cultural moderators. Computers in Human Behavior, 50, 418-430. 
Baptista, G., \& Oliveira, T. (2017). Why so serious? Gamification impact in the acceptance of mobile banking services. Internet Research, 27(1), 118-139.

Bhatiasevi, V. (2016). An extended UTAUT model to explain the adoption of mobile banking. Information Development, 32(4), 799-814.

Budi Agus Riswandi, Aspek Hukum Internet Banking, Persada, Jogjakarta, 2005.

Chin, W. W. (1998). The Partial Least Squares Aproach to Structural Equation Modeling. Modern Methods for Business Research, 295, 336.

Chemingui, Hella \& ben lallouna, Hajer. (2013). Resistance, motivations, trust and intention to use mobile financial services. The International Journal of Bank Marketing. 31. 10.1108/IJBM-12-2012-0124.

Choudrie, J., Junior, C. O., McKenna, B., \& Richter, S. (2018). Understanding and conceptualising the adoption, use and diffusion of mobile banking in older adults: A research agenda and conceptual framework. Journal of Business Research, 88(July), 449-465.

Denzin, N.K. and Lincoln, Y.S. (2005), "Introduction: the discipline and practice of qualitative research",in Denzin,

N.K. and Lincoln, Y.S. (Eds), The Sage Handbook of Qualitative Research, 2nd ed., Sage, Thousand Oaks, CA.

Dwivedi, Yogesh \& Rana, Nripendra \& Jeyaraj, Anand \& Clement, Marc \& Williams, Michael. (2017). Reexamining the Unified Theory of Acceptance and Use of Technology (UTAUT): Towards a Revised Theoretical Model. Information Systems Frontiers. 21. 1-16. 10.1007/s10796-017-9774-y.

El-Masri, Mazen \& Tarhini Ali. (2017). Factors affecting the adoption of e-learning systems in Qatar and USA : Extending the Unified Theory of Acceptance and Use of Technology 2 (UTAUT2). Education Tech Research Dev. DOI 10.1007/s11423-016-9508-8.

Farah, M. F., Hasni, M. J., \& Abbas, A. K. (2018). Mobile-banking adoption: Empirical evidence from the banking sector in Pakistan. International Journal of Bank Marketing, 36(7), 1386-1413. doi:10.1108/ijbm-102017-0215.

Ghozali, I., \& Latan, H. (2015). Partial Least Square Konsep, Teknik dan Aplikasi Menggunakan Program SmartPLS 3.0. BP Undip, Semarang.

Goncalves, G., Oliveira, T. and Cruz-Jesus, F. (2018), "Understanding individual-level digital divide: evidence of an African country", Computers in Human Behavior, Vol. 87 No. 2, pp. 276-291.

Gupta, K., Manrai, R. and Goel, U. (2019), "Factors influencing adoption of payments banks by Indian customers: extending UTAUT with perceived credibility”, Journal of Asia Business Studies, Vol. 13 No. 2 , pp. 173-195

Hidayat, Anwar.(2018). Partial Least Square (PLS), Pengertian, Fungsi, Tujuan, Cara. https://www.statistikian.com/2018/08/pengertian-partial-least-square-pls.html diakses pada 03 November 2020 pukul 20.01 WIB.

Kapoor, K. K., Tamilmani, K., Rana, N. P., Patil, P., Dwivedi, Y. K., \& Nerur, S. (2018). Advances in social media research: Past, present and future. Information Systems Frontiers, 20(3), 531-558.

Kuisma, T., Laukkanen, T., \& Hiltunen, M. (2007). Mapping the reasons for resistance to Internet banking: A means-end approach. International Journal of Information Management, 27(2), 75-85.

Lee, K. C., \& Chung, N. (2009). Understanding factors affecting trust in and satisfaction with mobile banking in Korea: A modified DeLone and McLean's model perspective. Interacting with Computers, 21(5-6), 385-392.

Lemeshow, S., Hosmer Jr, D. W., Klar, J., \& Lwanga, S. K. (1990). Adequacy of sample size in health studies. Chichester: Wiley. p 1

Mahfuz, M.A., Khanam Liza \& Mutharasu, S.A. (2016). The influence of website quality on m-banking services adoption in Bangladesh : applying the UTAUT2 model using PLS. International Conference on Electrical, Electronic and Optimization Techniques (ICEEOT).

Mahfuz, M.A., Hu Wang., Khanam, Liza. 2016. The Influence of Cultural Dimensions and Website Quality onm-banking Services Adoption in Bangladesh: Applying the UTAUT2 Model Using PLS. Wuhan International Conference on e-Business. http://aisel.aisnet.org/whiceb2016/18.

Malaquias, Rodrigo \& Hwang, Yujong. (2016). An empirical study on trust in mobile banking: A developing country perspective. Computers in Human Behavior. 54. 453-461. 10.1016/j.chb.2015.08.039.

Malaquias, F., Malaquias, R., \& Hwang, Y. (2018). Understanding the determinants of mobile banking adoption: A longitudinal study in Brazil. Electronic Commerce Research and Applications, 30, 1-7.

Mehrad, D., \& Mohammadi, S. (2017). Word of Mouth impact on the adoption of mobile banking in Iran. Telematics and Informatics, 34(7), 1351-1363.

Martins, C., Oliveira, T., \& Popovic, A. (2014). Understanding the internet banking adoption: A unified theory of acceptance and use of technology and perceived risk application. International Journal of Information Management, 34(1), 1-13.

Merhi, M., Hone, K., \& Tarhini, A.(2019). A cross-cultural study of the intention to use mobile banking between Lebenese and British consumers : Extending UTAUT2 with security, privacy and trust. Technology in Society. https://doi.org/10.1016/j.techsoc.2019.101151. 
Merhi, M., Hone, K., Tarhini, A., \& Ameen, N. (2020). An empirical examination of the moderating role of age and gender in consumer mobile banking use: A cross-national, quantitative study. Journal of Enterprise Information Management, Ahead-of-print (Ahead-of-print). doi:10.1108/jeim-03-2020-0092.

Oliveira, T., Faria, M., Thomas, M.A. and Popovic, A. (2014), "Extending the understanding of mobile banking adoption: when UTAUT meets TTF and IT", International Journal of Information Management, Vol. 34 No. 5, pp. 689-703.

Owusu Kwateng, K., Osei Atiemo, K.A., \& Appiah, (2018). Acceptance and use of mobile banking: an application of UTAUT2. Journal of Enterprise Information Management, https:// doi.org/10.1108/JEIM-032018-0055

Ozturk, A. B., Bilgihan, A., Nusair, K., \& Okumus, F. (2016). What keeps the mobile hotel booking users loyal? Investigating the roles of self-efficacy, compatibility, perceived ease of use, and perceived convenience. International Journal of Information Management, 36(6), 1350-1359.

Pangarso, Astadi. (2019). Belajar SEM PLS. https://medium.com/@astadipangarso/belajar-sem-pls6fa358c2d9a3 diakses pada 03 November pk. 20.13 WIB.

Pijpers, G.G. and van Montfort, K. (2005), “An investigation of factors that influence senior executives to accept innovations in information technology", International Journal of Management, Vol. 22 No. 4, pp. 542-555.

Purwanto, Edi \& Loisa, Julia. (2020). The Intention and Use Behaviour of the Mobile Banking System in indonesia: UTAUT Model. Technology Reports of Kansai University. 62.

Rana, N. P., Dwivedi, Y. K., Lal, B., Williams, M. D., \& Clement, M. (2017). Citizens' adoption of an electronic government system: Towards a unified view. Information Systems Frontiers, 19(3), 549-568.

Rana, N. P., Dwivedi, Y. K., \& Williams, M. D. (2015). A meta-analysis of existing research on citizen adoption of e-government. Information Systems Frontiers, 17(3), 547-563.

Rahi, Samar \& Mansour, Majeed \& Alghizzawi, Mahmoud \& Alnaser, Feras. (2019). Integration of UTAUT model in internet banking adoption context: The mediating role of performance expectancy and effort expectancy. Journal of Research in Interactive Marketing. ahead-of-print. 10.1108/JRIM-02-2018-0032.

Sampaio, C. H., Ladeira, W. J., \& Santini, F. D. O. (2017). Apps for mobile banking and customer satisfaction: A cross-cultural study. International Journal of Bank Marketing, 35(7), 1133-1153.

Sarstedt, M., Hair, J.F., Cheah, J.H., Becker, J.M., \& Ringle, C.M. (2019). How to specify, estimate, and validate higher-order constructs in PLS-SEM. Australasian Marketing Journal, Vol. 27, pp.197-211. DOI :https://doi.org/10.1016/j.ausmj.2019.05.003

Shareef, M. A., Dwivedi, Y. K., Kumar, V., \& Kumar, U. (2017). Content design of advertisement for consumer exposure: Mobile marketing through short messaging service. International Journal of Information Management, 37(4), 257-268.

Siyoto, Sandu \& Sodik, Ali. (2015). Dasar Metodologi Penelitian. Literasi Media Publishing. Yogyakarta : Sleman.

Tabsh, B. (2012), "An investigation of the adoption by banks and acceptance by bank customers of internet banking in the sultanate of Oman", unpublished doctoral dissertation, Cardiff Metropolitan University

Tam, C., \& Oliveira, T. (2017). Understanding mobile banking individual performance: The DeLone \& McLean model and the moderating effects of individual culture. Internet Research, 27(3), 538-562.

Tarhini, A., El-Masri, M., Ali, M. and Serrano, A. (2016), "Extending the UTAUT model to understand the customers' acceptance and use of internet banking in Lebanon: a structural equation modeling approach", Information Technology \& People, Vol. 29No. 4, pp. 830-849.

Talukder, M., Quazi, A. and Sathye, M. (2014), "Mobile phone banking usage behaviour: an Australian perspective", Australasian Accounting, Business and Finance Journal, Vol. 8 No. 4, pp. 83-104.

Thusi, Philie \& Maduku, D.K (2020). South African Millennials' Acceptance and use of retail mobile banking apps : An integrated perspective. Computers in Human Behavior. https://doi.org/10.1016/j.chb.2020.106405.

Tiago Oliveira, Miguel Faria, Manoj Abraham Thomas, Aleš Popovič. (2014). Extending the understanding of mobile banking adoption: When UTAUT meets TTF and ITM, International Journal of Information Management, Volume 34, No.5.

Tiwari, R. and Buse, S. (2007), The Mobile Commerce Prospects: A Strategic Analysis of Opportunities in the Banking Sector, Hamburg University Press, Hamburg.

Venkatesh, V., Morris, M.G. and Ackerman, P.L. (2000). A longitudinal field investigation of gender differences in individual technology adoption decision-making processes. Organizational Behavior and Human Decisio Processes, Vol. 83 No. 1, pp. 33-60.

Venkatesh, V., Morris, M.G., Davis, G.B. and Davis, F.D. (2003). User acceptance of information technology: toward a unified view. MIS Quarterly, Vol. 27 No. 3, pp. 425-478.

Venkatesh, V., Thong, J.Y. and Xu, X. (2012), "Consumer acceptance and use of information technology: extending the unified theory of acceptance and use of technology”, MIS Quarterly, Vol. 36 No. 1, pp. 157 178.

Wang, Y.S., Lin, H.H. and Luarn, P. (2006), "Predicting consumer intention to use mobile service", Information Systems Journal, Vol. 16 No. 2, pp. 157-179. 
Yu, Chian-Son. (2012). Factors affecting individuals to adopt mobile banking: Empirical evidence from the UTAUT model. Journal of Electronic Commerce Research. 13. 104-121.

Zhou, T. (2012). Examining mobile banking user adoption from the perspectives of trust and flow experience. Information Technology and Management, 13(1), 27-37.

Zhou, Tao \& Lu, Yaobin \& Wang, Bin. (2010). Integrating TTF and UTAUT to explain mobile banking user adoption. Computers in Human Behavior. 26. 760-767. 10.1016/j.chb.2010.01.013. 